\title{
112. Finding of Lawsonite-bearing Rock as a Pebble in a Jurassic Conglomerate Bed in the Southeastern Part of Mindoro Island, Philippines
}

\author{
By Tadashi SATo and Yotaro SEKI \\ Geological Institute, University of Tokyo and Department of Foundation \\ Engineering, Saitama University, Urawa
}

(Comm. by Teiichi Kobayashi, M. J. A., Sept. 12, 1972)

Introduction. The writers have recently found a lawsonitebearing metavolcanic rock as a pebble from a conglomerate bed in the Jurassic Mansalay formation exposed along the Sipatag River in southeast Mindoro Island (Fig. 1). This is the first finding of lawsonite-bearing metamorphic rock in the Philippines. Petrographic characters of lawsonite-bearing rock and the geological significance of this discovery will be briefly discussed in this paper.

Geology of Jurassic Mansalay formation in southeast Mindoro Island. The Mansalay formation is known to be distributed only in a small area of south-central Mindoro Island. The formation is mainly composed of clastic sediments and probably overlies the metamorphic terrain with angular unconformity (Andal et al., 1968). Its age is Middle to Upper Jurassic judged by a rich ammonite fauna discovered in situ.

The conglomerate bed from which a pebble of lawsonite-bearing rock was found occupies a stratigraphically lower horizon of the formation, and its age is not older than Middle Jurassic. The pebbles of the conglomerate are altered volcanics, crystalline schists, red chert, greywacke, and slate, in addition to Fusulinid-bearing limestones. The Fusulinids from the limestone pebbles are reported to be Schwagerina and Verbeekina, both of Permian age (Andal, 1966).

Similar rocks to those found as pebbles of the conglomerate have a wide distribution around Mindoro Island: the Fusulinid-bearing limestones of the Permian age are known from Carabao Island to the southeast (Andal, 1966), and have recently been discovered along the South China Sea coast of northern Palawan (late Mr. C. A. Reyes, personal communication, and unpublished data of Hashimoto and Sato, 1972). Similar but more crystalline limestone beds are intercalated within the metamorphic sequence in northern Mindoro Hashimoto and Sato, 1968) and also in Romblon Island.

Crystalline schists are distributed in Mindoro and the surrounding area as well. Although the geologic structure of the metamor- 


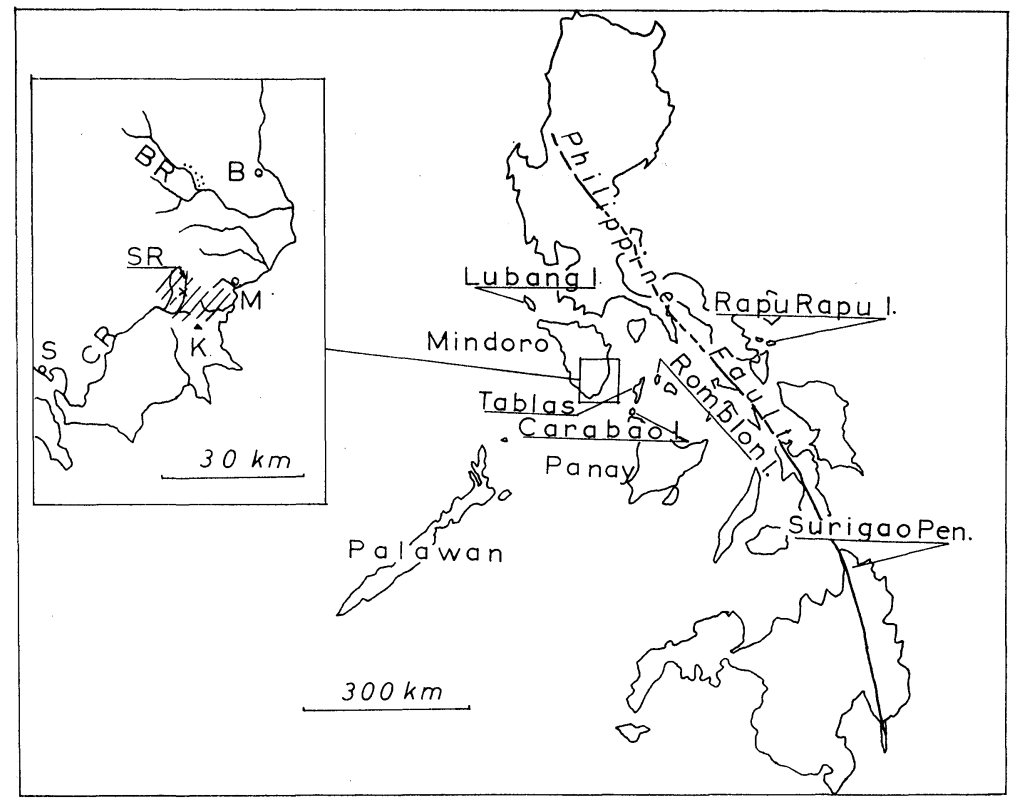

Fig. 1. Index map. The inset map shows the distribution of pre-Jurassic crystalline schists (dotted) and Mansalay formation (hatched) in southern Mindoro Island. B: Bongabong, M: Mansalay, S: San Jose, K: Knob Peak, BR: Bongabong River, SR: Sipatag River, CR: Caguray River, cross mark: locality of the conglomerate.

phic rocks still is a matter of dispute, these crystalline schists are believed to form a metamorphic belt extending to northern Palawan, and to be truncated by the Philippine Fault (Kimura et al., 1968). In fact, rocks of different metamorphic facies are discernible within the belt: the greenschist facies rocks are found in Lubang, northern Mindoro, western Panay, and southern Tablas, whereas the amphibolite facies are found in southern Mindoro (Bongabong River area, Fig. 1), and northern Tablas Islands. This metamorphic belt forms the basement of the Jurassic formation.

Petrographic characters of lawsonite-bearing rock. The pebble has a well rounded form, is $5 \times 3 \times 2 \mathrm{~cm}$ in size, and is dark greenish in color. Microscopic observation indicates that the rock was derived from aphanitic-mafic volcanic rock which has probably been composed of fine-grained crystals of augite, plagioclase, magnetite, and some glassy matrix. The volcanic rock has been completely altered into the assemblage of lawsonite, albite, chlorite, quartz, and sphene with a very small amount of epidote. The average size of single crystals of lawsonite is as follows : $0.04 \mathrm{~mm}$ in length and $0.01 \mathrm{~mm}$ in width. 
Table I. Optical properties of albite, chlorite, and lawsonite in lawsonite-bearing rock found as a pebble of the Mansalay formation, Mindoro, Philippines

\begin{tabular}{|c|c|c|c|c|c|}
\hline & \multicolumn{2}{|c|}{ Albite } & \multicolumn{2}{|c|}{ Chlorite } & Lawsonite \\
\hline$\alpha$ & 1.530 & 0.002 & 1.620 & 0.002 & $1.665 \quad 0.002$ \\
\hline$\gamma$ & 1.541 & 0.002 & 1.626 & 0.002 & $1.684 \quad 0.002$ \\
\hline $2 \mathrm{~V}$ & - & & - & & $(+) 83^{\circ}$ \\
\hline
\end{tabular}

Table II. $X$-ray powder patterns of a mixture of lawsonite, albite and quartz separated from the specimen of a pebble in the Mansalay formation, Mindoro, Philippines

\begin{tabular}{cclccl}
\hline $2 \theta$ & I & Minerals & $2 \theta$ & I & Minerals \\
\hline 13.40 & m & Lawsonite & 27.39 & w & Lawsonite \\
13.77 & w & Albite & 27.88 & s & Albite \\
18.13 & m & Lawsonite & 29.58 & w & Lawsonite \\
19.35 & w & Lawsonite & 30.10 & w & Lawsonite \\
20.78 & w & Quartz & 30.42 & $\mathrm{~m}$ & Albite \\
21.30 & $\mathrm{~m}$ & Lawsonite & 30.80 & $\mathrm{~m}$ & Albite \\
22.03 & $\mathrm{~m}$ & Albite & 32.80 & $\mathrm{~s}$ & Lawsonite \\
23.00 & w & Albite & 33.40 & $\mathrm{~m}$ & Lawsonite \\
23.42 & w & Albite & 34.02 & $\mathrm{~s}$ & Lawsonite \\
24.25 & $\mathrm{~s}$ & Albite Lawsonite & 36.82 & $\mathrm{~m}$ & Lawsonite \\
25.32 & w & Albite & 36.90 & $\mathrm{~m}$ & Lawsonite \\
26.66 & $\mathrm{~m}$ & Quartz & 37.50 & $\mathrm{w}$ & Lawsonite \\
\hline
\end{tabular}

$\mathrm{s}$ : strong, $\mathrm{m}$ : medium, w: weak.

There are some veins $(0.2-0.4 \mathrm{~mm}$ in width) of the following mineral assemblages: quartz-lawsonite-chlorite, quartz-albite, and quartz-carbonate.

Optical properties of albite, chlorite and lawsonite are given in Table I. Uniaxial characters of vein-forming carbonate indicate that the carbonate is not aragonite but calcite.

A mixture of lawsonite with small amounts of albite and quartz was separated from host-rock by magnetic separator and heavy liquid techniques. X-ray powder patterns of the mixture are given in Table II.

Chlorite and albite stably coexist in this specimen. Neither sodic amphibole nor sodic pyroxene were observed in this metavolcanic rock.

Geological meaning of lawsonite-bearing rock. Lawsonite has a chemical composition of $\mathrm{CaAl}_{2} \mathrm{Si}_{2} \mathrm{O}_{8} \cdot 2 \mathrm{H}_{2} \mathrm{O}$ (anorthite plus 2 molecules of water). The hydrous chemical composition, high density (3.1) and high packing index (total ionic volume/cell volume $=0.64$ ) of lawsonite indicate that it must be stable at relatively high solid 
and water pressure conditions. Experimental studies which have been done for the last ten years show that lawsonite can stably be formed at higher pressure conditions than $3 \mathrm{~kb}$ (Newton and Kennedy, 1963; Crawford and Fyfe, 1965; Nitsch, 1968; Liou, 1971).

The occurrence of lawsonite in nature is confined to regional metamorphic terrains in which high pressure and low temperature conditions prevailed (facies series of highest pressure type, high pressure type and intermediate pressure type after Seki, 1969). Regional metamorphisms which form lawsonite-bearing rock are characterized by the intrusion of mafic-ultramafic rocks with little or no igneous activity involving granitic magma. In Japan, for example, lawsonite occurs in the Sangun and Sanbagawa regional metamorphic belts which are characterized by great amounts of mafic and ultramafic intrusives. No lawsonite has been reported, however, from the regional metamorphic belts of Hida and Ryoke which are situated on the inner side of the Sangun and Sanbagawa belts, and are characterized by the occurrence of metamorphic rocks formed at relatively steep geothermal gradients and by granitic intrusion as a major energy source. Metamorphic rocks in the Franciscan belt of the California Coast Ranges, which are the type locality of the highest pressure type facies series of Seki (1969), lawsonite is usually associated with glaucophane and/or jadeitic pyroxene (Ernst et al., 1970). The absence of glaucophane and jadeite in the specimen treated in this paper indicates that the metamorphic terrains from which the pebble specimen came may belong to the facies series of high or intermediate pressure type.

Metamorphic terrains with lawsonite-bearing rocks are widely developed in the Circum Pacific Belt occurring in South America, Mexico, the California Coast Ranges, the Japanese Islands, Celebes, New Caledonia, and in the New Zealand Alpine Belt (Ernst et al., 1970). The Philippine Islands which are located between the Japanese Islands and Celebes clearly belong to the Circum Pacific Belt. The occurrence of lawsonite-bearing metamorphic rocks could be expected from the Philippine Arc.

Irving (1950) reported the occurrence of glaucophane schist in the basement complex developed in Surigao Peninsula of eastern Mindanao. Mr. Tsuji of Nanyo Bussan Co. found glaucophane schist in the basement complex having a bedded cupriferous iron deposit of Rapu Rapu Island, Albay (personal communication). These occurrences of glaucophane schists indicate the presence of the blueschist facies regional metamorphic terrains in the eastern side of the Philippine Fault, 200-300 km east of Mindoro Island. However, the source 
area from which pebbles in the conglomerate of the Mansalay formation were derived, can be limited to the areas surrounding southern Mindoro Island. Thus the lawsonite-bearing pebble can not have come from a great distance. The present discovery of lawsonitebearing rock indicates that an area (or belt) regionally metamorphosed at relatively high pressure conditions must also have been formed on the western side of the Philippine Fault (probably in Mindoro and its surrounding area) before the deposition of the Jurassic formation. Metamorphic characters of the area must have been similar to those of the Sangun metamorphic belt of Japan, which is in the Inner Belt of Southwest Japan and was formed in pre-Upper Triassic time. It should be remembered that the Mansalay formation is tectonically comparable to strata of the Tetori group which are post-orogenic sediments of Middle-Upper Jurassic age and overlie the basement (including Sangun metamorphics) with unconformity.

Acknowledgement. The writers are indebted to $\mathrm{Em}$. Prof. Teiichi Kobayashi and Prof. Toshio Kimura of the University of Tokyo for their stimulating suggestions. They would also like to thank Mr. Tsugio Someya and Mr. Shintaro Tsuji of Nanyo Bussan Co. Ltd. for providing them with unpublished information.

\section{References}

Andal, P. P. (1966): Phil. Geol., 20, 14-22.

Andal, D. R. et al. (1968): Geol. and Palaeont. S. E. Asia, 4, 179-197.

Crawford, W. A., and Fyfe, W. S. (1965): Amer. Jour. Sci., 263, 262-270.

Ernst, W. G. et al. (1970): Geol. Soc. Am., Mem., 124, 1-276.

Hashimoto, W., and Sato, T. (1968): Geol. and Palaeont. S. E. Asia, 5, 192-210. Irving, E. M. (1950): Phil. Jour. Sci., 79, 267-307.

Kimura, T. et al. (1968) : Geol. and Palaeont. S. E. Asia, 4, 156-178.

Liou, J. G. (1971) : Jour. Petr., 12, 379-411.

Newton, R. G., and Kennedy, G. C. (1963) : Jour. Geophys. Res., 68, 2967-2983.

Nitsch, K. H. (1968): Naturwissenschaften, 55, 388.

Seki, Y. (1969): Jour. Geol. Soc. Japan, 75, 255-266. 